\title{
Adrenal Mass
}

National Cancer Institute

\section{Source}

National Cancer Institute. Adrenal Mass. NCI Thesaurus. Code C35409.

An abnormal growth in the adrenal gland. 